\title{
PD-L1 Expression Is a Prognostic Factor in Patients with Thoracic Esophageal Cancer Treated Without Adjuvant Chemotherapy
}

\author{
AKIYUKI WAKITA ${ }^{1}$, SATORU MOTOYAMA ${ }^{1}$, HIROSHI NANJO ${ }^{2}$, YUSUKE SATO ${ }^{1}$, \\ KEI YOSHINO ${ }^{1}$, TOMOHIKO SASAKI ${ }^{1}$, YUTA KAWAKITA ${ }^{1}$, JIAJIA LIU ${ }^{1}$, \\ KAZUHIRO IMAI $^{1}$, HAJIME SAITO ${ }^{1}$ and YOSHIHIRO MINAMIYA ${ }^{1}$ \\ Departments of ${ }^{1}$ Thoracic Surgery, and ${ }^{2}$ Pathology, Akita University Graduate School of Medicine, Akita, Japan
}

\begin{abstract}
Background/Aim: Programmed death-1 ligand 1 (PD-L1) induces apoptosis of tumor-reactive T-cells, that enables tumors to evade immune defense and thus furthers their growth. Our aim was to determine whether PD-L1 expression status correlates with prognosis in patients with advanced thoracic esophageal squamous cell carcinoma. Patients and Methods: The PD-L1 expression status of 177 patients treated with esophagectomy without preoperative therapy was evaluated immunohistochemically using tissue microarray. We then statistically analyzed the relationships between PD-L1 expression status and clinicopathological features and survival. Results: In patients undergoing surgery alone, PD-L1 expression was significantly positivity associated with a better prognosis. By contrast, there were no significant correlations between PD-L1 expression and clinicopathological features or outcomes in patients treated with surgery plus postoperative adjuvant chemotherapy. Conclusion: PD-L1 positivity in advanced thoracic esophageal squamous cell carcinoma may be predictive of a positive prognosis in patients treated without adjuvant chemotherapy.
\end{abstract}

Esophageal cancer is one of the most difficult types of gastrointestinal cancers to treat and is the sixth leading cause of death worldwide (1). Although advances in the comprehensive treatment of esophageal cancer have enabled improvement of outcomes (2-4), the extremely aggressive behavior of this cancer type continues to limit the 5-year survival rate among these patients (5).

Correspondence to: Akiyuki Wakita, Department of Thoracic Surgery, Akita University Graduate School of Medicine, 1-1-1 Hondo, Akita, 010-8543, Japan. Tel: +81 188846132, Fax: +81 188362615, e-mail:wakita@gipc.akita-u.ac.jp

Key Words: PD-L1, esophageal cancer, prognosis, immunochemistry.
Programmed death-1 (PD-1) is a co-stimulatory molecule expressed on T-cells, B-cells and myeloid cells, which provides an inhibitory signal during T-cell activation (6-8). The PD-1 ligands PD-L1 and PD-L2 are cell-surface glycoproteins belonging to the B7 family (9-12). Previous studies have shown that PD-1/PD-L1 ligation inhibits T-cell growth and cytokine secretion $(10,12)$. Moreover, recent studies suggest that tumor-associated PD-L1 induces apoptosis in tumor-reactive T-cells, thereby enabling tumors to evade host immune defenses and grow (13). Aberrant PDL1 expression has been detected in various human malignancies and, in most of these cases, PD-L1 expression correlates with a poor prognosis and high malignancy (1416). On the other hand, recent studies have also suggested that PD-L1 may provide a positive signal leading to T-cell proliferation $(9,17)$. Consequently, the prognostic significance of PD-L1 expression in human esophageal cancer is not entirely clear. The purpose of this study was to clarify whether PD-L1 expression status correlates with the prognosis of patients with advanced thoracic esophageal squamous cell carcinoma.

\section{Patients and Methods}

Patients. During the period from January 2001 to December 2010, a total of 459 patients with esophageal cancer underwent esophagectomy at Akita University Hospital. Among these patients, we enrolled 177 with T2-4 thoracic esophageal cancer who had undergone curative esophagectomy with no pre-operative treatment. Esophageal cancer stage and the treatment strategy were defined for each patient at a conference attended by radiologists, physicians and surgeons. The disease was classified according to the International Union against Cancer tumor-node-metastasis (TNM) Classification of Malignant Tumors (seventh edition) (18).

Because this study was conducted before the publication of the JCOG9907 study (19), all the patients were treated with esophagectomy alone or esophagectomy followed by adjuvant chemotherapy which was regarded as the standard therapy at that time in Japan (20). Whether or not to administer adjuvant 
chemotherapy was determined based on the pathological status and clinical condition of the patient after the surgery. The adjuvant chemotherapy was administered according to the guidelines and algorithms for esophageal cancer treatment edited by the Japan Esophageal Society (20).

Surgery. Our standard operative procedure is right transthoracic or thoracoscopic esophagectomy with two- or three-field lymph node dissection. For the patients in this study, three-field lymph node dissection of the mediastinal (involving the periesophageal region and areas around the trachea and bilateral main bronchus), abdominal (involving the perigastric region and areas around the celiac axis), and cervical (involving the bilateral periesophageal region and supraclavicular region) lymph nodes were performed. We commonly perform reconstruction by inserting a gastric tube via the posterior mediastinal route.

Adjuvant chemotherapy. Based on the pathological results, initial administration of adjuvant chemotherapy was started within 2 months after esophagectomy. Some patients declined adjuvant chemotherapy or were not eligible because of their clinical condition. Details of the adjuvant chemotherapy are described elsewhere (19). In brief, the chemotherapy consisted of protracted infusion of 5fluorouracil $\left(800 \mathrm{mg} / \mathrm{m}^{2} /\right.$ day $)$ on days $1-5$, combined with cisplatin $\left(80 \mathrm{mg} / \mathrm{m}^{2} /\right.$ day) on day 1 . This protocol was repeated twice with 3 week intervals in between. All patients were followed-up using procedures designed to detect recurrence of their cancer. Follow-up consisted of physical examination, blood tests, chest X-rays and neck/chest/abdominal computed tomography. As a general rule, patients visited the hospital every 2 months for 5 years after their surgery. Neck/chest/abdominal computed tomography was carried out every 6 months for 2 years and at least every year thereafter.

Esophageal squamous cell carcinoma tissue microarray. An esophageal squamous cell carcinoma tissue microarray (TMA) was constructed at the Pathology Institute, Toyama, Japan using 177 paraffin blocks of primary tumor. Areas of squamous cell carcinoma were identified by pathologists from hematoxylin/eosin-stained sections from each paraffin block. To account for cancer heterogeneity, three randomly selected cores measuring $0.6 \mathrm{~mm}$ in diameter were collected from each paraffin block and placed in the TMA.

Immunohistochemistry. Four-micrometer-thick sections from the TMA were deparaffinized in xylene and ethanol, placed in 10 mmol/1 Tris buffer ( $\mathrm{pH}$ 9.0) containing $1 \mathrm{mmol} / \mathrm{l}$ EDTA and irradiated with microwaves $(750 \mathrm{~W})$ for $5 \mathrm{~min}$. Endogenous peroxidase activity was blocked by incubating the sections for 15 min in $3 \% \mathrm{H}_{2} \mathrm{O}_{2}$, and nonspecific binding was blocked by incubation for $30 \mathrm{~min}$ in $10 \%$ goat serum (Nichirei, Tokyo, Japan). The specimens were then incubated for $60 \mathrm{~min}$ with rabbit monoclonal antibody to PD-L1 (1:200 dilution, 13684; Cell Signaling Technology, Danvers, MA, USA) as the primary antibody. This was followed by incubation first in blocking buffer and then with a peroxidase-conjugated, anti-rabbit antibody (Histofine Mouse stain Kit ${ }^{\circledR}$; Nichirei) for 30 min each. Thereafter, the tissue sections were developed by incubation for $5 \mathrm{~min}$ with 3 , 3'diaminobenzidine tetrahydrochloride (Nichirei), and the antigen was visualized using biotin, horseradish peroxidase-conjugated streptavidin and 3, 3'-diaminobenzidine peroxidase substrate according to the manufacturer's instructions. Finally, the sections were counterstained with Gill hematoxylin, dehydrated and mounted. Photomicrographs of the immunostaining were taken for analysis using a NanoZoomer Digital Pathology Virtual Slide Viewer (Hamamatsu Photonics, version 1.2.33, Hamamatsu, Shizuoka, Japan). For each tumor, the percentage of PD-L1-positive area (decimal scale from $0-100 \%$ ) within the whole cancer area in three cores was determined by two surgeons blinded to the clinical data. We preliminarily arbitrarily set several cut-off points in order to select the best value. Significant differences for survival were found when the PD-L1 positive area was $10 \%$ or more within the whole cancer area. Hence samples were deemed positive when the stained area was $10 \%$ or more of the whole cancer area and patients were partitioned by this value into PD-L1-positive and PD-L1negative groups.

Biostatical analysis. The median and frequency were used to summarize the characteristics of the patients in the PD-L1-positive and PD-L1-negative groups. The Wilcoxon test (for continuous variables) or $\chi^{2}$ and Fisher exact tests (for categorical variables) were used to compare the differences between these groups. Survival length was determined from the date of surgery to death or the date of the last clinical attendance. Survival curves were derived using the Kaplan-Meier method, and differences between curves were analyzed using the log-rank test. Cox's proportional hazards regression model was used for multivariate analyses. Tumor location, $\mathrm{T}$ status, $\mathrm{N}$ status, pathological stage, and PD-L1 expression were included in the multivariate model. All analyses were performed using JMP 10 (SAS Institute, Cary, NC, USA), which yielded two-sided $p$-values. Values of $p<0.05$ were considered significant.

\section{Results}

PD-L1 Expression in cancer cells. PD-L1 localized primarily at the cell membrane, although it was also distributed in the cytoplasm. Figure 1 shows representative images of samples staining positively (Figure 1a) and negative (Figure 1b) for PD-L1. Among the 177 patients studied, 49 (27.7\%) were defined as being positive for PD-L1 expression and 128 as negative based on immunohistochemical analysis.

Clinicopathological associations of PD-L1 expression. Among the 177 patients studied, 105 received adjuvant chemotherapy after esophagectomy (surgery-adjuvant group) and 72 did not (surgery-alone group). The clinicopathological features of the patients partitioned with respect to PD-L1 expression are summarized separately in Table I. The median patient age at esophagectomy was 71 years (range $=38-82$ years) in the surgery-alone group and 64 (range $=38-78$ years) in the surgery-adjuvant group. Among those treated with surgery alone, 15 were defined as PD-L1-positive based on immunohistochemical analysis; the remaining 57 were PDL1-negative. Statistical analysis indicated that early tumor stage and lower recurrence rate correlated with PD-L1 positivity ( $p=0.029$ and $p=0.009$, respectively, Table I). Among those treated with surgery plus adjuvant chemotherapy, 34 were defined as PD-L1-positive, while the 

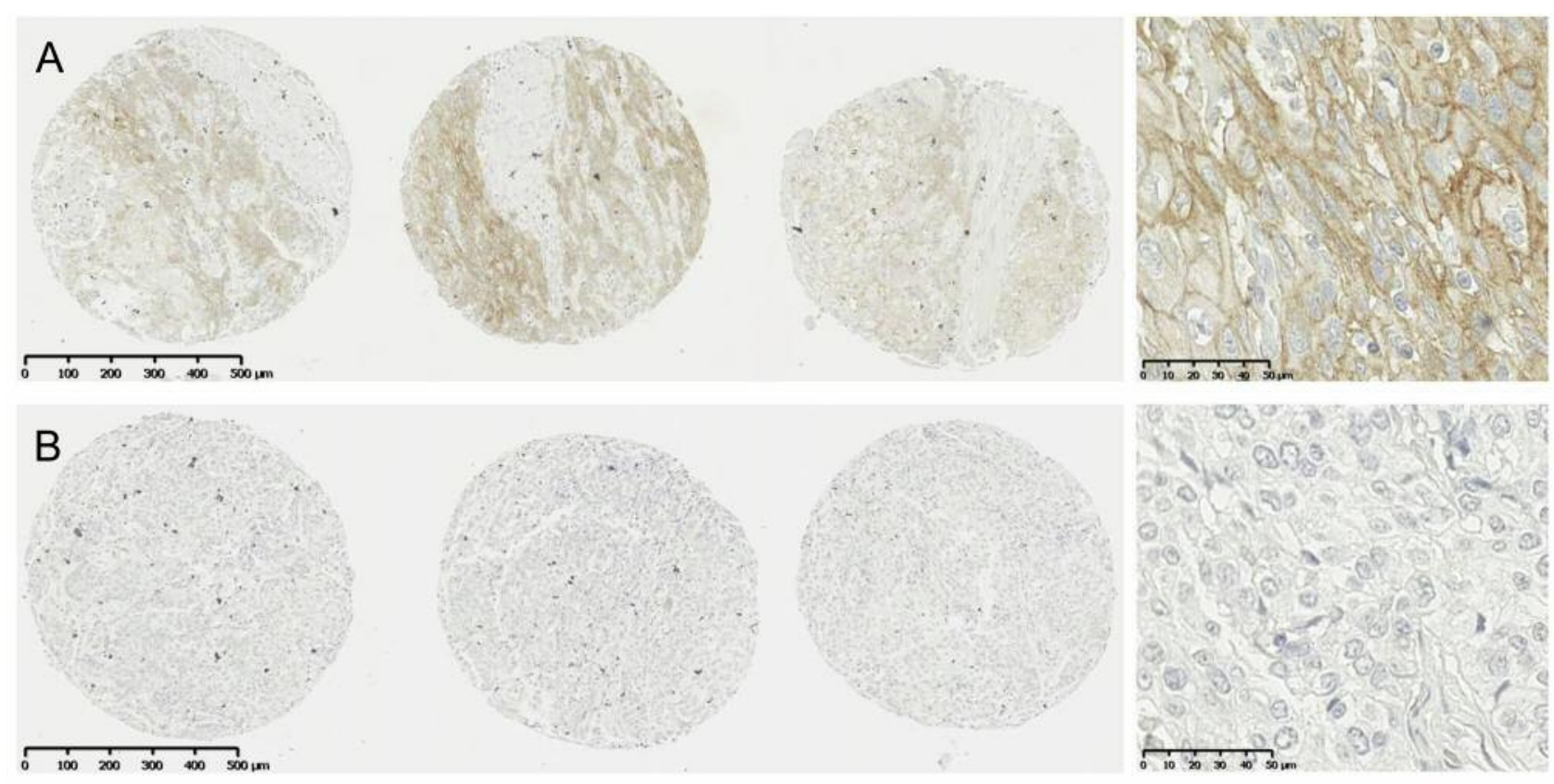

Figure 1. Photomicrographs showing exemplary immunochemical staining of triple cores from a tissue microarray revealing programmed death-1 ligand 1 (PD-L1) expression in esophageal squamous cell carcinoma. A: Positive expression of PD-L1. PD-L1 was localized at the membrane and in the cytoplasm. B: Negative expression of PD-L1.

remaining 71 were PD-L1-negative. There were no significant differences in the clinicopathological features between the PD-L1-positive and PD-L1-negative patients in the surgeryadjuvant group.

Prognostic effect of PD-L1 expression. In the surgery-alone group, Kaplan-Meier curves showed that 5-year diseasespecific survival (DSS) and disease-free survival (DFS) were significantly better among PD-L1-positive patients ( $p=0.0158$ and $p=0.0148$, respectively, Figure 2 ). Although the same tendency was found for 5-year overall survival (OS), the difference in OS between PD-L1-positive and negative patients was not statistically significant $(p=0.0808)$. In the surgery-adjuvant group, there were no significant differences in 5-year OS, DSS or DFS between PD-L1positive and -negative patients. Consistent with these findings, univariate analysis of age $(\geq 70 v s .<70$ years $)$, gender, depth of invasion (T2 vs. T3-4), lymph node metastasis (N1-3 vs. N0), pathological stage (IIIA-IIIC $v s$. IB-IIB), tumor differentiation (poor $v s$. not poor), postoperative pneumonia (yes $v s$. no) and PD-L1 expression (negative $v s$. positive) showed lymph node metastasis, pathological stage, tumor differentiation and PD-L1 expression status to be significant prognostic factors affecting 5-year DSS in the surgery-alone group ( $p=0.0005$, $p=0.0005, p=0.0297$ and $p=0.0045$, respectively, Table II). Furthermore, in a multivariate analysis using a Cox regression model, PD-L1 expression status was determined to be a significant independent prognostic factor $(p=0.0144$, Table III).

\section{Discussion}

In this study, we demonstrated that among patients treated with surgery without adjuvant chemotherapy for thoracic esophageal cancer, PD-L1-positive patients were found to have a significantly better prognosis than PD-L1-negative patients. On the other hand, there were no significant differences in survival among patients receiving postoperative adjuvant chemotherapy. We also showed that PD-L1 expression status was an independent prognostic factor in patients treated with esophagectomy without adjuvant chemotherapy.

The PD-L1-PD-1 interaction serves as an important regulatory check against excessive adoptive immune responses to antigens and autoimmunity (21). Thus, upon Tcell receptor activation, PD-L1 acts as a negative regulator of the immune response $(22,23)$. In addition, experiments using murine models showed that PD-L1 is a key mediator enabling tumor cells to evade the immune system both in vitro and in vivo (10-13, 22-24). Immunochemical treatments targeting the PD-L1-PD-1 axis are currently under investigation and have shown evidence of antitumor activity (25-27). In addition, it has been suggested that PD-L1 expression in tumor cells 
Surgery alone
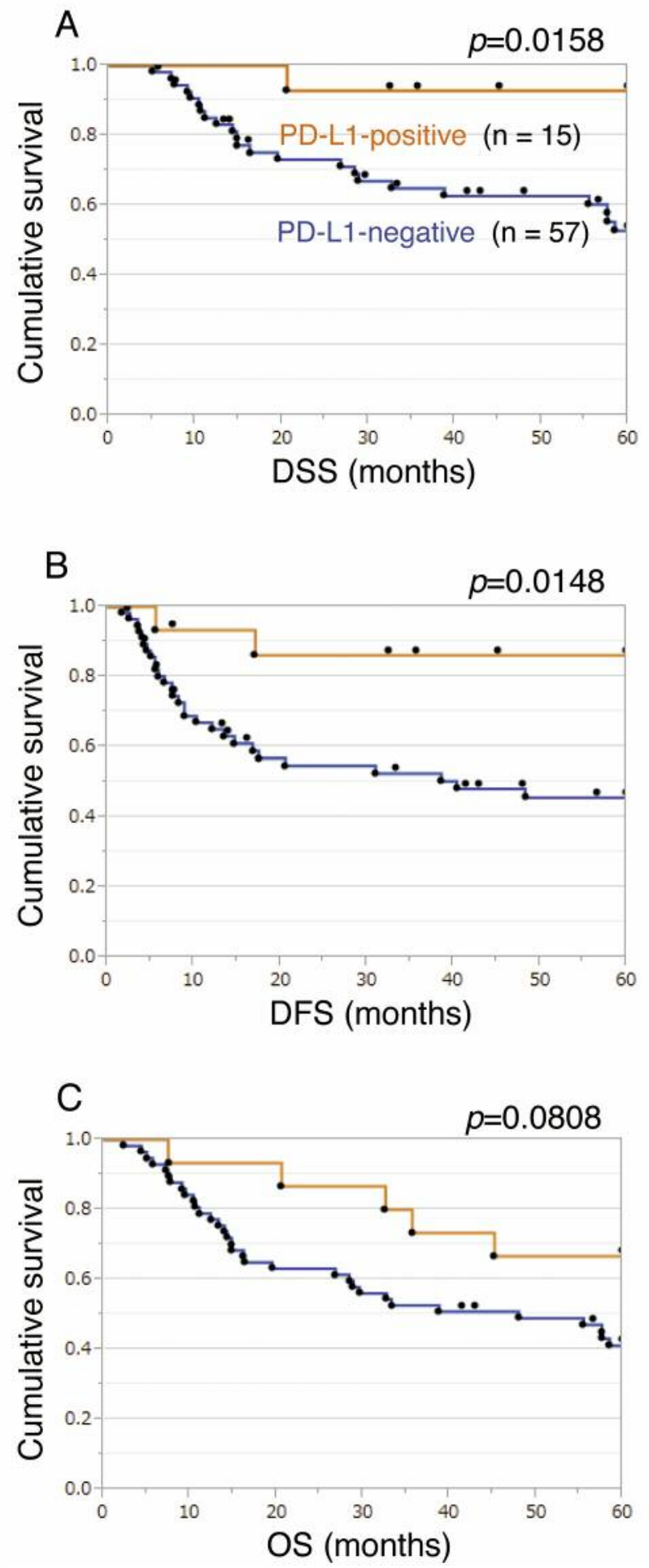

Surgery + adjuvant
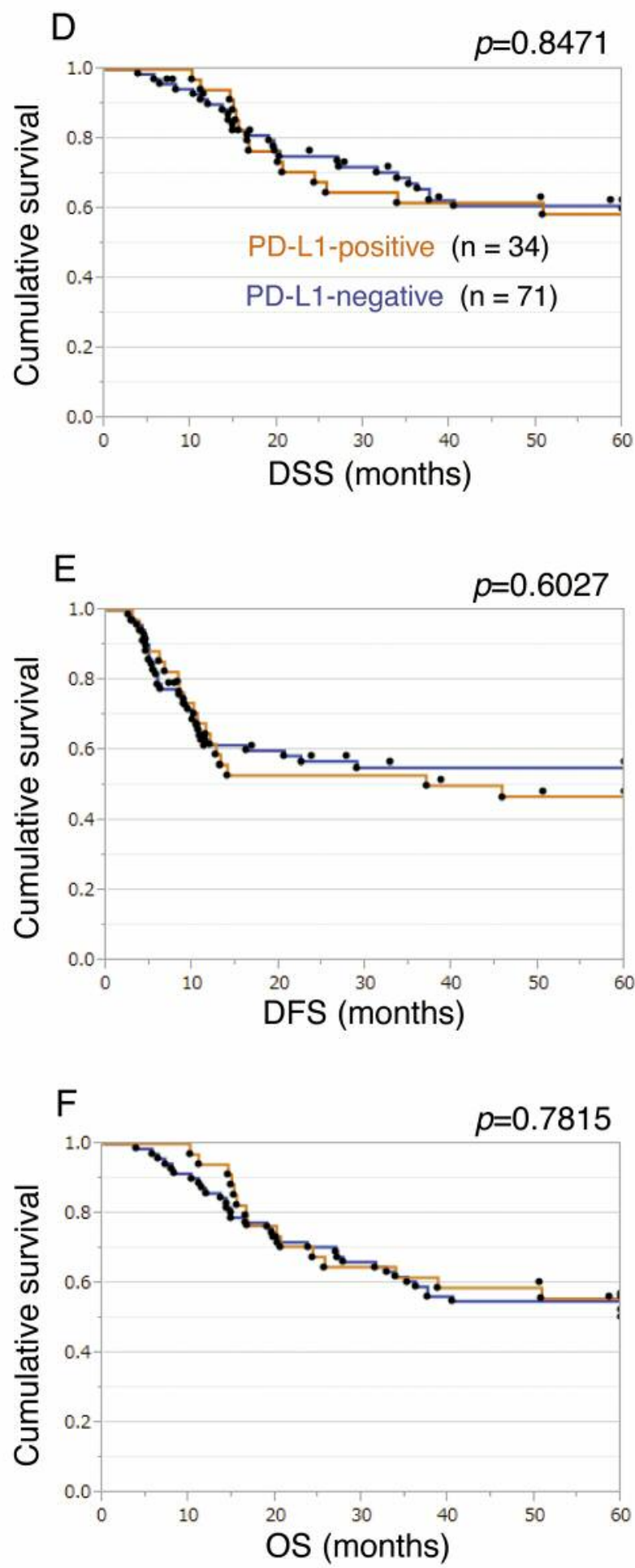

Figure 2. Kaplan-Meier curves assessing the impact of programmed death-1 ligand 1 (PD-L1) expression on disease-specific (DSS) (A, D), diseasefree $(D F S)(B, E)$ and overall $(O S)(C, F)$ survival among PD-L1-positive and PD-L1-negative patients in the group treated with surgery alone and that treated with surgery plus adjuvant therapy. PD-L1-positive patients had significantly longer DSS (A) and DFS (B) than PD-L1-negative patients in the group treated with surgery alone. Dots above the line indicate censored cases; dots on the line indicate failed cases. 
Table I. Clinicopathological features of patients with esophageal cancer (EC).

\begin{tabular}{|c|c|c|c|c|c|c|}
\hline \multirow[b]{2}{*}{ Factor } & \multicolumn{3}{|c|}{$\begin{array}{l}\text { Surgery alone }(\mathrm{n}=72) \\
\text { PD-L1, } \mathrm{n}\end{array}$} & \multicolumn{3}{|c|}{$\begin{array}{l}\text { Adjuvant group }(\mathrm{n}=105) \\
\text { PD-L1, } \mathrm{n}\end{array}$} \\
\hline & Positive $(n=15)$ & Negative $(n=57)$ & $p$-Value & Positive $(n=34)$ & Negative $(n=71)$ & $p$-Value \\
\hline Gender & & & 0.631 & & & 0.257 \\
\hline Female & 2 & 5 & & 3 & 14 & \\
\hline Male & 13 & 52 & & 31 & 57 & \\
\hline Median age at surgery (range), years & $70(57-82)$ & $71(38-78)$ & & $62.5(49-72)$ & $64(38-78)$ & \\
\hline Tumor location & & & 0.055 & & & 0.781 \\
\hline Upper & 1 & 0 & & 1 & 4 & \\
\hline Middle & 7 & 40 & & 22 & 47 & \\
\hline Lower & 7 & 17 & & 11 & 20 & \\
\hline Depth of invasion & & & 0.174 & & & 0.804 \\
\hline $\mathrm{T} 2$ & 5 & 8 & & 7 & 11 & \\
\hline $\mathrm{T} 3$ & 9 & 47 & & 25 & 56 & \\
\hline $\mathrm{T} 4 \mathrm{a}$ & 1 & 2 & & 2 & 4 & \\
\hline Lymph node metastasis & & & 0.525 & & & 0.343 \\
\hline NO & 8 & 20 & & 9 & 12 & \\
\hline N1 & 2 & 4 & & 1 & 5 & \\
\hline $\mathrm{N} 2$ & 3 & 16 & & 10 & 17 & \\
\hline N3 & 1 & 6 & & 4 & 19 & \\
\hline N4 & 1 & 11 & & 10 & 18 & \\
\hline Pathological stage & & & $0.029^{*}$ & & & 0.056 \\
\hline IB & 5 & 2 & & 3 & 0 & \\
\hline IIA & 3 & 17 & & 6 & 11 & \\
\hline IIB & 0 & 1 & & 1 & 5 & \\
\hline IIIA & 4 & 19 & & 7 & 27 & \\
\hline IIIB & 1 & 9 & & 6 & 14 & \\
\hline IIIC & 2 & 9 & & 11 & 14 & \\
\hline Tumor differentiation & & & 0.403 & & & 0.132 \\
\hline Well & 2 & 8 & & 3 & 16 & \\
\hline Moderate & 11 & 32 & & 15 & 33 & \\
\hline Poor & 2 & 17 & & 16 & 22 & \\
\hline Adverse events & & & 0.610 & & & 0.669 \\
\hline Positive & 9 & 30 & & 11 & 26 & \\
\hline Negative & 6 & 27 & & 23 & 45 & \\
\hline Anastomotic leakage & & & 0.532 & & & 0.609 \\
\hline Positive & 4 & 11 & & 4 & 11 & \\
\hline Negative & 11 & 46 & & 30 & 60 & \\
\hline Recurrent nerve paralysis & & & 0.582 & & & 0.666 \\
\hline Bilateral & 1 & 1 & & 0 & 1 & \\
\hline Unilateral & 3 & 11 & & 9 & 15 & \\
\hline Negative & 11 & 45 & & 25 & 55 & \\
\hline Pneumonia & & & 0.372 & & & 0.059 \\
\hline Occurred & 6 & 16 & & 1 & 11 & \\
\hline Absent & 9 & 41 & & 33 & 60 & \\
\hline Recurrence of EC. & & & $0.009 *$ & & & 0.535 \\
\hline Positive & 2 & 28 & & 18 & 33 & \\
\hline Negative & 13 & 29 & & 16 & 38 & \\
\hline Prognosis & & & 0.062 & & & 0.701 \\
\hline Alive & 9 & 17 & & 16 & 33 & \\
\hline Died from EC & 1 & 23 & & 15 & 28 & \\
\hline Died from other cancer. & 1 & 2 & & 1 & 1 & \\
\hline Died from other disease & 4 & 15 & & 2 & 9 & \\
\hline
\end{tabular}

*Statistically significant.

could serve as a predictive tool (15). However, the clinical relevance of PD-L1 expression was poorly investigated until recently $(13,24)$. Ohigashi et al. were the first to declare that
PD-L1 expression was related to a poorer prognosis in patients with esophageal cancer (28). Chen et al. then reported that OS was significantly poorer among patients with 
Table II. Univariate analysis of 5-year disease-specific survival in patients with esophageal cancer not receiving adjuvant chemotherapy.

\begin{tabular}{|c|c|c|c|}
\hline \multirow[b]{2}{*}{ Variable } & \multicolumn{3}{|c|}{ Univariate Cox proportional hazards model } \\
\hline & HR & $95 \% \mathrm{CI}$ & $p$-Value \\
\hline PD-L1 expression: Negative $(\mathrm{n}=57) v s$. positive $(\mathrm{n}=15)$ & 7.969 & $1.678-142.568$ & $0.0045^{*}$ \\
\hline Age: $\geq 70(\mathrm{n}=44)$ vs. $<70(\mathrm{n}=28)$ & 1.567 & $0.688-3.874$ & 0.2906 \\
\hline Gender: Male $(\mathrm{n}=65)$ vs. female $(\mathrm{n}=7)$ & 2.656 & $0.560-47.517$ & 0.2638 \\
\hline Depth of invasion: T2 $(\mathrm{n}=13) v s . \mathrm{T} 3-4(\mathrm{n}=59)$ & 1.133 & $0.376-2.820$ & 0.8059 \\
\hline Lymph node metastasis: Positive $(\mathrm{n}=44)$ vs. negative $(\mathrm{n}=28)$ & 5.203 & $1.960-17.934$ & $0.0005 *$ \\
\hline Pathological stage: IIIA-IIIC $(\mathrm{n}=44) v s$. IB-IIB $(\mathrm{n}=28)$ & 5.203 & $1.960-17.934$ & $0.0005^{*}$ \\
\hline Tumor differentiation: Poor $(\mathrm{n}=19)$ vs. not poor $(\mathrm{n}=53)$ & 2.660 & $1.108-6.040$ & $0.0297 *$ \\
\hline Postoperative pneumonia: Yes $(\mathrm{n}=22) v s$. no $(\mathrm{n}=50)$ & 1.460 & $0.591-3.322$ & 0.3941 \\
\hline
\end{tabular}

PD-L1: Programmed death-1 ligand 1; HR: hazard ratio; CI: confidence interval. *Statistically significant.

Table III. Multivariate analysis of 5-year disease-specific survival in patients with esophageal cancer not receiving adjuvant chemotherapy.

\begin{tabular}{|c|c|c|c|}
\hline & HR & $95 \% \mathrm{CI}$ & $p$-Value \\
\hline PD-L1 expression: Negative $(\mathrm{n}=57) v s$. positive $(\mathrm{n}=15)$ & 6.677 & $1.361-120.601$ & $0.0144^{*}$ \\
\hline Age: $\geq 70(\mathrm{n}=44)$ vs. $<70(\mathrm{n}=28)$ & 1.135 & $0.426-3.149$ & 0.8012 \\
\hline Gender: Male $(\mathrm{n}=65)$ vs. female $(\mathrm{n}=7)$ & 2.275 & $0.453-41.374$ & 0.3730 \\
\hline Lymph node metastasis: Positive $(\mathrm{n}=44)$ vs. negative $(\mathrm{n}=28)$ & 2.081 & $0.275-18.948$ & 0.5153 \\
\hline Pathological stage: IIIA-IIIC $(\mathrm{n}=44) v s$. IB-IIB $(\mathrm{n}=28)$ & 2.362 & $0.317-20.691$ & 0.4390 \\
\hline Tumor differentiation: Poor $(\mathrm{n}=19)$ vs. not poor $(\mathrm{n}=53)$ & 1.987 & $0.758-5.151$ & 0.1593 \\
\hline
\end{tabular}

PD-L1: Programmed death-1 ligand 1; HR: hazard ratio; CI: confidence interval. *Statistically significant.

PD-L1-positive tumors than among those with PD-L1negative ones (29). Tumor-infiltrating T-lymphocytes (TILs) are thought to be a manifestation of the host immune response to the tumor, and induction of apoptosis and subsequent elimination of TILs by PD-L1 is thought to be a mechanism by which the immune response to the tumor is suppressed. However, previous studies reported no significant correlation between PD-L1 expression and TILs, although the two cohorts were small $(28,29)$.

The prognostic value of PD-L1 in malignant disease is unclear, as earlier studies have reported conflicting results. Whereas a positive correlation between PD-L1 expression and prognosis was reported in non-small cell lung cancer and mismatch repair (MMR)-proficient colorectal cancer $(30,31)$, no relation was found between PD-L1 expression and survival in osteosarcoma, melanoma or MMR-deficient colorectal cancer (31-33), and there was correlation with adverse outcomes in gastric cancer and renal cell carcinoma (34-37).

We observed that in patients with esophageal cancer treated surgically without adjuvant chemotherapy, PD-L1 positivity is related to better 5-year DSS and DFS rates than in patients without PD-L1 expression. Similar associations were recently reported by Chen et al. (38), who assessed 536 patients with esophageal squamous cell carcinoma and found that PD-L1 expression was a positive prognostic factor. They also showed that PD-L1 positivity correlated with an upper esophageal location, well-differentiated tumor, absence of lymph node metastasis and early tumor stages, which suggests PD-L1 expression is an indicator of less aggressive tumors. These results may be somewhat surprising, as expression of an immunosuppressive molecule appears to correlate with improved outcomes. Future investigations of the relation between PD-L1 and TIL function may reveal the underlying mechanism. It has been suggested that the presence of particular TIL subsets, such as CD8-positive cytotoxic T-cells, correlates with a better prognosis in various malignancies (39-46). Tumor infiltration by CD8positive T-cells is itself an independent prognostic factor in both squamous cell carcinoma and adenocarcinoma (42). Moreover, cooperation between CD4- and CD8-positive Tcells reportedly leads to an improved prognosis in patients with esophageal squamous cell carcinoma (47). Evidence also suggests that PD-L1 may provide a positive signal via an as yet unknown receptor, which induces T-cell proliferation and secretion of interleukin-10 and interferon$\gamma$, thereby activating antitumor effects $(9,17)$. In addition, localized PD-L1 expression reportedly promotes organspecific autoimmunity as well as alloimmunity (48). 
An important finding in this study is that contrary to the results in patients undergoing surgery alone, there was no significant difference in survival between PD-L1-positive and -negative patients treated with surgery plus adjuvant therapy. This suggests chemotherapy not only has a direct cytotoxic effect on tumor cells, it also affects the tumor immune system. We conjecture that tumoral expression of PD-L1 may be reduced by chemotherapy in patients with esophageal cancer. Although the relationship between tumoral PD-L1 expression and chemotherapy has not been fully investigated, Lesterhuis et al. reported that platinum dephosphorylates signal transducer and activator of transcription 6, resulting in decreased PD-L2 expression in both human dendritic cells and tumor cells (49).

The clinical significance of PD-L1 expression in esophageal cancer has not yet been firmly established. Therefore, clarification of the distribution and expression rate of PD-L1 in cancer and its clinical relevance are important issues for future investigation.

\section{Conclusion}

PD-L1 expression was detected in $27.7 \%$ of patients with esophageal squamous cell carcinoma. In contrast to earlier findings that PD-L1 expression contributes to suppression of antitumor immune responses, our study indicates that PD-L1 expression in squamous cell esophageal carcinoma has a positive impact on the prognosis of patients treated by esophagectomy without adjuvant chemotherapy.

Disclosure: All Authors state that they have no conflict of interest to disclose interest in regard to this study.

\section{Acknowledgements}

This work was supported, in part, by Grants-in-Aid for Scientific Research from the Ministry of Education, Culture, Science, Sports and Technology of Japan.

\section{References}

1 Jemal A, Bray F, Center MM, Ferlay J, Ward E and Forman D: Global cancer statistics. CA Cancer J Clin 61(2): 69-90, 2011.

2 Herskovic A, Martz K, al-Sarraf M, Leichman L, Brindle J, Vaitkevicius V, Cooper J, Byhardt R, Davis L and Emami B: Combined chemotherapy and radiotherapy compared with radiotherapy alone in patients with cancer of the esophagus. $\mathrm{N}$ Engl J Med 326(24): 1593-1598, 1992.

3 Cooper JS, Guo MD, Herskovic A, Macdonald JS, Martenson JA Jr., Al-Sarraf M, Byhardt R, Russell AH, Beitler JJ, Spencer S, Asbell SO, Graham MV and Leichman LL: Chemoradiotherapy of locally advanced esophageal cancer: long-term follow-up of a prospective randomized trial (RTOG 85-01). Radiation Therapy Oncology Group. JAMA 281(17): 1623-1627, 1999.

4 Shitara K and Muro K: Chemoradiotherapy for treatment of esophageal cancer in Japan: current status and perspectives. Gastrointest Cancer Res 3(2): 66-72, 2009.
5 Tachimori Y, Ozawa S, Numasaki H, Fujishiro M, Matsubara H, Oyama T, Shinoda M, Toh Y, Udagawa $H$ and Uno T: Registration Committee for Esophageal Cancer of the Japan Esophageal Society: Comprehensive Registry of Esophageal Cancer in Japan, 2009. Esophagus 13: 110-137, 2016.

6 Ishida Y, Agata Y, Shibahara K and Honjo T: Induced expression of PD-1, a novel member of the immunoglobulin gene superfamily, upon programmed cell death. EMBO J 11(11): 3887-3895, 1992.

7 Nishimura H, Okazaki T, Tanaka Y, Nakatani K, Hara M, Matsumori A, Sasayama S, Mizoguchi A, Hiai H, Minato N and Honjo T: Autoimmune dilated cardiomyopathy in PD-1 receptordeficient mice. Science 291(5502): 319-322, 2001.

8 Sharpe AH and Freeman GJ: The B7-CD28 superfamily. Nat Rev Immunol 2(2): 116-126, 2002.

9 Dong H, Zhu G, Tamada K and Chen L: B7-H1, a third member of the B7 family, co-stimulates T-cell proliferation and interleukin-10 secretion. Nat Med 5(12): 1365-1369, 1999.

10 Freeman GJ, Long AJ, Iwai Y, Bourque K, Chernova T, Nishimura H, Fitz LJ, Malenkovich N, Okazaki T, Byrne MC, Horton HF, Fouser L, Carter L, Ling V, Bowman MR, Carreno BM, Collins M, Wood CR and Honjo T: Engagement of the PD1 immunoinhibitory receptor by a novel B7 family member leads to negative regulation of lymphocyte activation. J Exp Med 192(7): 1027-1034, 2000.

11 Tseng SY, Otsuji M, Gorski K, Huang X, Slansky JE, Pai SI, Shalabi A, Shin T, Pardoll DM and Tsuchiya H: B7-DC, a new dendritic cell molecule with potent costimulatory properties for T-cells. J Exp Med 193(7): 839-846, 2001.

12 Latchman Y, Wood CR, Chernova T, Chaudhary D, Borde M, Chernova I, Iwai Y, Long AJ, Brown JA, Nunes R, Greenfield EA, Bourque K, Boussiotis VA, Carter LL, Carreno BM, Malenkovich N, Nishimura H, Okazaki T, Honjo T, Sharpe AH and Freeman GJ: PD-L2 is a second ligand for PD-1 and inhibits T-cell activation. Nat Immunol 2(3): 261-218, 2001.

13 Dong H, Strome SE, Salomao DR, Tamura H, Hirano F, Flies DB, Roche PC, Lu J, Zhu G, Tamada K, Lennon VA, Celis E and Chen L: Tumor-associated B7-H1 promotes T-cell apoptosis: a potential mechanism of immune evasion. Nat Med 8(8): 793$800,2002$.

14 Muenst S, Schaerli AR, Gao F, Däster S, Trella E, Droeser RA, Muraro MG, Zajac P, Zanetti R, Gillanders WE, Weber WP and Soysal SD: Expression of programmed death ligand 1 (PD-L1) is associated with poor prognosis in human breast cancer. Breast Cancer Res Treat 146(1): 15-24, 2014.

15 Zhang Y, Kang S, Shen J, He J, Jiang L, Wang W, Guo Z, Peng $\mathrm{G}$, Chen $\mathrm{G}$, He J and Liang W: Prognostic significance of programmed cell death 1 (PD-1) or PD-1 ligand 1 (PD-L1) Expression in epithelial-originated cancer: a meta-analysis. Medicine (Baltimore) 94(6): e515, 2015.

16 Tjin EP, Krebbers G, Meijlink KJ, van de Kasteele W, Rosenberg EH, Sanders J, Nederlof PM, van de Wiel BA, Haanen JB, Melief CJ, Vyth-Dreese FA and Luiten RM: Immune-escape markers in relation to clinical outcome of advanced melanoma patients following immunotherapy. Cancer Immunol Res 2(6): 538-546, 2014.

17 Wang S, Bajorath J, Flies DB, Dong H, Honjo T and Chen L: Molecular modeling and functional mapping of B7-H1 and B7DC uncouple costimulatory function from PD-1 interaction. J Exp Med 197(9): 1083-1091, 2003. 
18 Sobin L, Gospodarowicz M and Wittekind C: International Union against Cancer. TNM Classification of Malignant Tumors. Seventh Edition. Chichester: Wiley-Blackwell, 2009.

19 Ando N, Kato H, Igaki H, Shinoda M, Ozawa S, Shimizu H, Nakamura T, Yabusaki H, Aoyama N, Kurita A, Ikeda K, Kanda T, Tsujinaka T, Nakamura $\mathrm{K}$ and Fukuda $\mathrm{H}$ : A randomized trial comparing postoperative adjuvant chemotherapy with cisplatin and 5-fluorouracil versus preoperative chemotherapy for localized advanced squamous cell carcinoma of the thoracic esophagus (JCOG9907). Ann Surg Oncol 19(1): 68-74, 2012.

20 Ando N, Iizuka T, Ide H, Ishida K, Shinoda M, Nishimaki T, Takiyama W, Watanabe H, Isono K, Aoyama N, Makuuchi H, Tanaka O, Yamana H, Ikeuchi S, Kabuto T, Nagai K, Shimada Y, Kinjo Y and Fukuda H: Surgery plus chemotherapy compared with surgery alone for localized squamous cell carcinoma of the thoracic esophagus: a Japan Clinical Oncology Group Study JCOG9204. J Clin Oncol 21(24): 4592-4596, 2003.

21 Mozaffarian N, Wiedeman AE and Stevens AM: Active systemic lupus erythematosus is associated with failure of antigenpresenting cells to express programmed death ligand-1. Rheumatology (Oxford) 47(9): 1335-41, 2008.

22 Nishimura $\mathrm{H}$, Nose M, Hiai H, Minato $\mathrm{N}$ and Honjo T: Development of lupus-like autoimmune diseases by disruption of the $P D-1$ gene encoding an ITIM motif-carrying immunoreceptor. Immunity 11(2): 141-151, 1999.

23 Nishimura $\mathrm{H}$ and Honjo T: PD-1: an inhibitory immunoreceptor involved in peripheral tolerance. Trends Immunol 22(5): 265268, 2001

24 Iwai Y, Ishida M, Tanaka Y, Okazaki T, Honjo T and Minato N: Involvement of PD-L1 on tumor cells in the escape from host immune system and tumor immunotherapy by PD-L1 blockade. Proc Natl Acad Sci USA 99(19): 12293-12797, 2002.

25 Sznol M and Chen L: Antagonist antibodies to PD-1 and B7-H1 (PD-L1) in the treatment of advanced human cancer. Clin Cancer Res 19(5): 1021-1034, 2013.

26 Brahmer JR, Tykodi SS, Chow LQ, Hwu WJ, Topalian SL, Hwu P, Drake CG, Camacho LH, Kauh J, Odunsi K, Pitot HC, Hamid O, Bhatia S, Martins R, Eaton K, Chen S, Salay TM, Alaparthy S, Grosso JF, Korman AJ, Parker SM, Agrawal S, Goldberg SM, Pardoll DM, Gupta A and Wigginton JM: Safety and activity of anti-PD-L1 antibody in patients with advanced cancer. N Engl J Med 366(26): 2455-2465, 2012.

27 Topalian SL, Hodi FS, Brahmer JR, Gettinger SN, Smith DC, McDermott DF, Powderly JD, Carvajal RD, Sosman JA, Atkins MB, Leming PD, Spigel DR, Antonia SJ, Horn L, Drake CG, Pardoll DM, Chen L, Sharfman WH, Anders RA, Taube JM, McMiller TL, Xu H, Korman AJ, Jure-Kunkel M, Agrawal S, McDonald D, Kollia GD, Gupta A, Wigginton JM and Sznol M: Safety, activity, and immune correlates of anti-PD-1 antibody in cancer. N Engl J Med 366(26): 2443-2454, 2012.

28 Ohigashi Y, Sho M, Yamada Y, Tsurui Y, Hamada K, Ikeda N, Mizuno T, Yoriki R, Kashizuka H, Yane K, Tsushima F, Otsuki $\mathrm{N}$, Yagita H, Azuma M and Nakajima Y: Clinical significance of programmed death-1 ligand-1 and programmed death-1 ligand2 expression in human esophageal cancer. Clin Cancer Res 11(8): 2947-2953, 2005.

29 Chen L, Deng H, Lu M, Xu B, Wang Q, Jiang J and Wu C: B7$\mathrm{H} 1$ expression associates with tumor invasion and predicts patient's survival in human esophageal cancer. Int J Clin Exp Pathol 7(9): 6015-6023, 2014
30 Velcheti V, Schalper KA, Carvajal DE, Anagnostou VK, Syrigos KN, Sznol M, Herbst RS, Gettinger SN, Chen L and Rimm DL: Programmed death ligand-1 expression in non-small cell lung cancer. Lab Invest 94(1): 107-116, 2014.

31 Droeser RA, Hirt C, Viehl CT, Frey DM, Nebiker C, Huber X, Zlobec I, Eppenberger-Castori S, Tzankov A, Rosso R, Zuber M, Muraro MG, Amicarella F, Cremonesi E, Heberer M, Iezzi G, Lugli A, Terracciano L, Sconocchia G, Oertli D, Spagnoli GC and Tornillo L: Clinical impact of programmed cell death ligand 1 expression in colorectal cancer. Eur J Cancer 49(9): 22332242,2013

32 Shen JK, Cote GM, Choy E, Yang P, Harmon D, Schwab J, Nielsen GP, Chebib I, Ferrone S, Wang X, Wang Y, Mankin H, Hornicek FJ and Duan Z: Programmed cell death ligand 1 expression in osteosarcoma. Cancer Immunol Res 2(7): 690-698, 2014.

33 Taube JM, Anders RA, Young GD, Xu H, Sharma R, McMiller TL, Chen S, Klein AP, Pardoll DM, Topalian SL and Chen L: Colocalization of inflammatory response with B7-h1 expression in human melanocytic lesions supports an adaptive resistance mechanism of immune escape. Sci Transl Med 4(127): 127ra37, 2012.

34 Qing Y, Li Q, Ren T, Xia W, Peng Y, Liu GL, Luo H, Yang YX, Dai XY, Zhou SF and Wang D: Upregulation of PD-L1 and APE1 is associated with tumorigenesis and poor prognosis of gastric cancer. Drug Des Devel Ther 9: 901-909, 2015.

35 Zhang L, Qiu M, Jin Y, Ji J, Li B, Wang X, Yan S, Xu R and Yang D: Programmed cell death ligand 1 (PD-L1) expression on gastric cancer and its relationship with clinicopathologic factors. Int J Clin Exp Pathol 8(9): 11084-91, 2015.

36 Thompson RH, Gillett MD, Cheville JC, Lohse CM, Dong H, Webster WS, Chen L, Zincke H, Blute ML, Leibovich BC and Kwon ED: Costimulatory molecule B7-H1 in primary and metastatic clear cell renal cell carcinoma. Cancer 104(10): 20842091, 2005.

37 Thompson RH, Kuntz SM, Leibovich BC, Dong H, Lohse CM, Webster WS, Sengupta S, Frank I, Parker AS, Zincke H, Blute ML, Sebo TJ, Cheville JC and Kwon ED: Tumor B7-H1 is associated with poor prognosis in renal cell carcinoma patients with long-term follow-up. Cancer Res 66(7): 33813385, 2006.

38 Chen K, Cheng G, Zhang F, Zhang N, Li D, Jin J, Wu J, Ying $\mathrm{L}$, Mao W and Su D: Prognostic significance of programmed death- 1 and programmed death-ligand 1 expression in patients with esophageal squamous cell carcinoma. Oncotarget $7(21)$ : 30772-30780, 2016.

39 Clemente CG, Mihm MC Jr., Bufalino R, Zurrida S, Collini P and Cascinelli N: Prognostic value of tumor infiltrating lymphocytes in the vertical growth phase of primary cutaneous melanoma. Cancer 77(7): 1303-1310, 1996.

40 Jass JR: Lymphocytic infiltration and survival in rectal cancer. J Clin Pathol 39(6): 585-589, 1986.

41 Naito Y, Saito K, Shiiba K, Ohuchi A, Saigenji K, Nagura H and Ohtani H: CD8+ T-cells infiltrated within cancer cell nests as a prognostic factor in human colorectal cancer. Cancer Res 58(16): 3491-3494, 1998.

42 Schumacher K, Haensch W, Röefzaad C and Schlag PM: Prognostic significance of activated CD8(+) T-cell infiltrations within esophageal carcinomas. Cancer Res 61(10): 3932-3936, 2001. 
43 Nakano O, Sato M, Naito Y, Suzuki K, Orikasa S, Aizawa M, Suzuki Y, Shintaku I, Nagura $\mathrm{H}$ and Ohtani H: Proliferative activity of intratumoral CD8(+) T-lymphocytes as a prognostic factor in human renal cell carcinoma: clinicopathologic demonstration of antitumor immunity. Cancer Res 61(13): 5132-5136, 2001.

44 Zhang L, Conejo-Garcia JR, Katsaros D, Gimotty PA, Massobrio M, Regnani G, Makrigiannakis A, Gray H, Schlienger K, Liebman MN, Rubin SC and Coukos G: Intratumoral T-cells, recurrence, and survival in epithelial ovarian cancer. $\mathrm{N}$ Engl $\mathrm{J}$ Med 348(3): 203-213, 2003.

45 Curiel TJ, Coukos G, Zou L, Alvarez X, Cheng P, Mottram P, Evdemon-Hogan M, Conejo-Garcia JR, Zhang L, Burow M, Zhu Y, Wei S, Kryczek I, Daniel B, Gordon A, Myers L, Lackner A, Disis ML, Knutson KL, Chen L and Zou W: Specific recruitment of regulatory T-cells in ovarian carcinoma fosters immune privilege and predicts reduced survival. Nat Med 10(9): 942-949, 2004.

46 Sato E, Olson SH, Ahn J, Bundy B, Nishikawa H, Qian F, Jungbluth AA, Frosina D, Gnjatic S, Ambrosone C, Kepner J, Odunsi T, Ritter G, Lele S, Chen YT, Ohtani H, Old LJ and Odunsi K: Intraepithelial CD8+ tumor-infiltrating lymphocytes and a high $\mathrm{CD}^{+} /$regulatory $\mathrm{T}$-cell ratio are associated with favorable prognosis in ovarian cancer. Proc Natl Acad Sci USA 102(51): 18538-18543, 2005.
47 Cho Y, Miyamoto M, Kato K, Fukunaga A, Shichinohe T, Kawarada Y, Hida Y, Oshikiri T, Kurokawa T, Suzuoki M, Nakakubo Y, Hiraoka K, Murakami S, Shinohara T, Itoh T, Okushiba S, Kondo S and Katoh H: CD4+ and CD8+ T-cells cooperate to improve prognosis of patients with esophageal squamous cell carcinoma. Cancer Res 63(7): 1555-1559, 2003.

48 Subudhi SK, Zhou P, Yerian LM, Chin RK, Lo JC, Anders RA, Sun Y, Chen L, Wang Y, Alegre ML and Fu YX: Local expression of B7-H1 promotes organ-specific autoimmunity and transplant rejection. J Clin Invest 113(5): 694-700, 2004.

49 Lesterhuis WJ, Punt CJ, Hato SV, Eleveld-Trancikova D, Jansen BJ, Nierkens S, Schreibelt G, de Boer A, Van Herpen CM, Kaanders JH, van Krieken JH, Adema GJ, Figdor CG and de Vries IJ: Platinum-based drugs disrupt STAT6-mediated suppression of immune responses against cancer in humans and mice. J Clin Invest 121(8): 3100-3108, 2011.

Received December 22, 2016

Revised February 8, 2017

Accepted February 13, 2017 